\title{
The prevalence and the socio - economic costs of smoking among the working age population in Latvia
}

\author{
A. Kokarevica \\ Rīga Stradinš̌ University, Riga, Latvia
}

\begin{abstract}
Smoking is a health problem, the costs of which include sickness, pain, grief and misery. But tobacco use also imposes a significant economic burden on society. One efficient way to assess the adverse health effects of smoking on a society is to translate smoking-caused illnesses, premature mortality, and productivity losses into economic terms, a universal marker for measuring the adverse effects of smoking. Due to the high proportion of smokers, Latvia faces high male mortality from smoking-related diseases; life expectancy for men in the age group 35-64 years is 2.44 years less than for non-smokers in the same age group, losing $37 \%$ of total lost years of life and therefore the government loses approximately 4588346 Euro per year from YPLL from smoking related diseases.
\end{abstract}

Key words: Smoking, socio-economic burden, YPLL, working-age population

\section{Introduction}

Since the late 1950s when Doll and Hill (1956) as one of the first identified a possible relationship between smoking and lung cancer, public health and medical researchers have investigated the effects of smoking and health for half a century [1]. As Doll and Hill already estimated in 1956 in their 54-month long follow-up study, the death rate of heavy smokers from lung cancer is approximately twenty times the death rate of non - smokers [2]. The U.S. Surgeon General Report has determined that smoking causes lung and laryngeal cancer, chronic obstructive pulmonary disease (COPD), coronary heart disease, stroke, and premature death, as well as other major diseases and health conditions [1]. As the U.S. Surgeon General Report reports, since the last report in 1964 cigarette smoking has been causally linked to the diseases of nearly all organs of the body. Even 50 years later research continues to newly identify diseases caused by smoking including such common diseases as diabetes mellitus, rheumatoid arthritis, and colorectal cancer [3]. It is clear that tobacco use is the leading preventable cause of death in high income countries, and increasingly in low- and middleincome countries. Today, tobacco use causes more than five million deaths per year among adults worldwide [4]. Smoking is a health problem, the costs of which include sickness, pain, grief and misery. But tobacco use also imposes a significant economic burden on society. In addition to the direct medical costs of treating tobacco-induced illnesses there are other indirect costs including loss of productivity, fire damage and environmental harm from cigarette litter and destructive farming practices. The total burden caused by tobacco products outweighs any economic benefit from their manufacture and sale [5]. Tobacco's cost to governments, to employers and to the environment includes social, welfare and health care spending, loss of foreign exchange in importing cigarettes; loss of land that could grow 
food; costs of fires and damage to buildings caused by careless smoking; environmental costs ranging from deforestation to collection of smokers' litter, absenteeism, decreased productivity, higher numbers of accidents and higher insurance premium [6]. When the costs of smoking to the health care system are clearer due to the research in past decades, the costs to the social care system are less known and have not previously been quantified.

These costs are not only those directly borne by local authorities but also the costs to those funding needs of their own care and the burden on friends and family careers. All these costs need to be considered by local authority officers and members as part of their strategic approach to care issues. Since smoking doubles the risk of developing care needs, it is highly relevant when considering the provision of preventive services. The burden on smokers as a result of illnesses caused by their addiction is significant. In the past it has been estimated that for every smoker who dies, 20 are living with a smoking-related illness. Research done in the UK showed that smokers are likely to need care on average nine years earlier than non-smokers. It also found that being a smoker doubled the chances of receiving care of any sort and increased the risk for ex-smokers by $25 \%$ [7]. The average smoking prevalence in EU is $28 \%$, according to the statistics, Latvia has one of the highest smoking rates in the EU (36\%), where our neighbors Lithuania and Estonia respectively $30 \%$ and $26 \%$. Most of the smokers in the EU are unemployed (49\%) which indicates that they do not pay taxes for the government, but receive social guaranties (for example government provided health care) [8]. Another instrument to measure the value of lives, lost prematurely, is the number of years of potential life lost (YPLL). YPLL denotes the number of years an individual would have lived had they not died of a smoking-attributable disease. The YPLL is determined the number of years of life expectancy remaining at the age of death [8]. Due to the high proportion of smokers, Latvia faces high male mortality from smoking-related diseases; life expectancy for men in the age group 35-64 years is 2.44 years less than for non-smokers in the same age group, losing $37 \%$ of total lost years of life.

The term 'costs of smoking' is defined as the difference between healthcare or other costs that actually occur due to smoking and the costs that would have occurred had there been no smoking [4]. The annual government spending from the GDP for the health care system in Latvia in the year 2013 was $3.16 \%$ (515.9 billion LVL). Most of the money was spent treating cardiovascular diseases and cancer as they are the leading cause of death in Latvia [9].

\section{Methodology}

To analyze the economic burden and prevalence of tobacco use among the working age population of Latvia a secondary data from the Latvian Center of Disease Prevention and Control (CDC) was used. To calculate the economic costs of YPLL we used the potential loss of income from the citizens of working age who have died from diseases that could potentially be closely related to the use of tobacco products, according to surveys mostly - cardiovascular diseases (CVD) and cancers [10]. Latvian statistics lacks data on how much one inhabitant contributes to the national economy. To get these data we used the recommendation of Latvian Ministry of Finance to equate the contribution to the country's GDP per 1 employed inhabitant. In this study, to calculate the economic burden we used the Central Statistics Bureau (CSB) data on GDP per 1 employed inhabitant (2012 25879 EUR) and the CDC data on mortality from Cardiovascular diseases (CVD) and cancer in the age group - 15-59 years, taking into account that smokers, on average, live about 8 years shorter life span than non-smokers. Studies show that on average smokers live about 8 years less than non-smokers and of the GDP per capita, we calculated the potential burden for the economy from CVD and cancer [11]. 


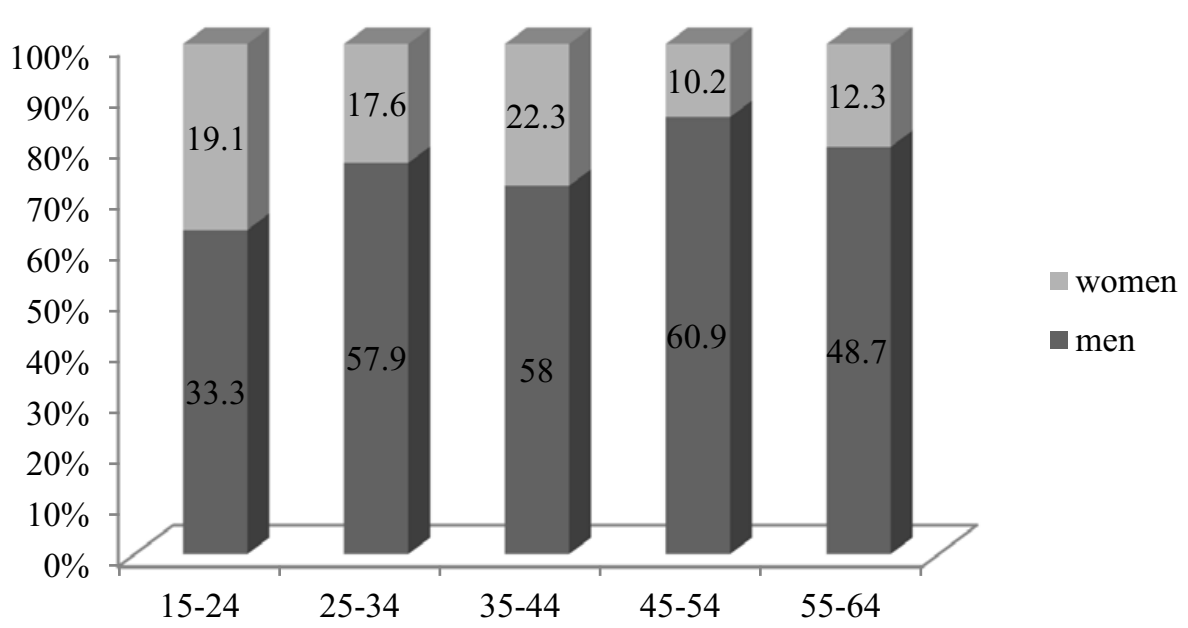

Figure 1. Prevalence of daily smokers (15 and more cigarettes per day), by age and gender.

\section{Results and discussion}

As shown in Fig. 1, especially among men, the smoking prevalence is very high. More than half of the men at working age smoke, especially high prevalence of smoking among men are in the economically most active age (25-54 years). Research data shows that smokers lose an average of 8 years of their potential life years where they could be active members of the society and contribute to the national economy [12]. As shown in the Fig. 1, more than a half of Latvian men of the working age smoke cigarettes every day. In average, $52.0 \%$ men and $17.6 \%$ women are daily smokers. The highest prevalence of smokers is in the age group which is the most economically active $-25-54$ years, which pose a greater risk to the national economy losing the working-age population [13]. In other countries women are more likely to smoke in younger age groups and they choose to smoke more cigarettes, posing a potential risk of developing chronic diseases in their later life. Whereas men are more likely to smoke more cigarettes in older age groups (Fig. 2). As shown in Fig. 2, men smoke more (one package a day) in the most economic active group (35+). That poses a risk of developing chronic diseases and loss from the labor market, creating a treat for national health and social security system. U.S. data shows that the prevalence of current cigarette smoking first declined among men (between 1965 and in the 1990s), and then among women (since the 1980s). However, decline in the prevalence of smoking among adults (18 years of age and older) has appeared in recent years [3].

The CDC data shows that the mortality from cardiovascular diseases and malignant neoplasm of bronchi and lungs in the age group 15-59 was 1595 and 178 people (2013) [11]. The calculation shows that the total burden if based on the data from 2013 is Euro 4588 346 per year and in 8 years (when the people did not take part in the economy of the country) the government loses 36706776 Euro. Other studies have found that considering both the smoking-attributable healthcare costs and the value of lost productivity caused by smoking-attributable deaths and disability, a review article by Lightwood and Collins et al. (2000) concluded that the total economic costs of smoking represent a significant loss for the whole economy, reaching $2.1 \%-3.4 \%$ of gross domestic product (GDP) in Australia, $1.3 \%-2.2 \%$ of GDP in Canada, and $1.4 \%-1.6 \%$ of GDP in the United States [4]. The European Commission estimated that public health spending on smoking-attributable 


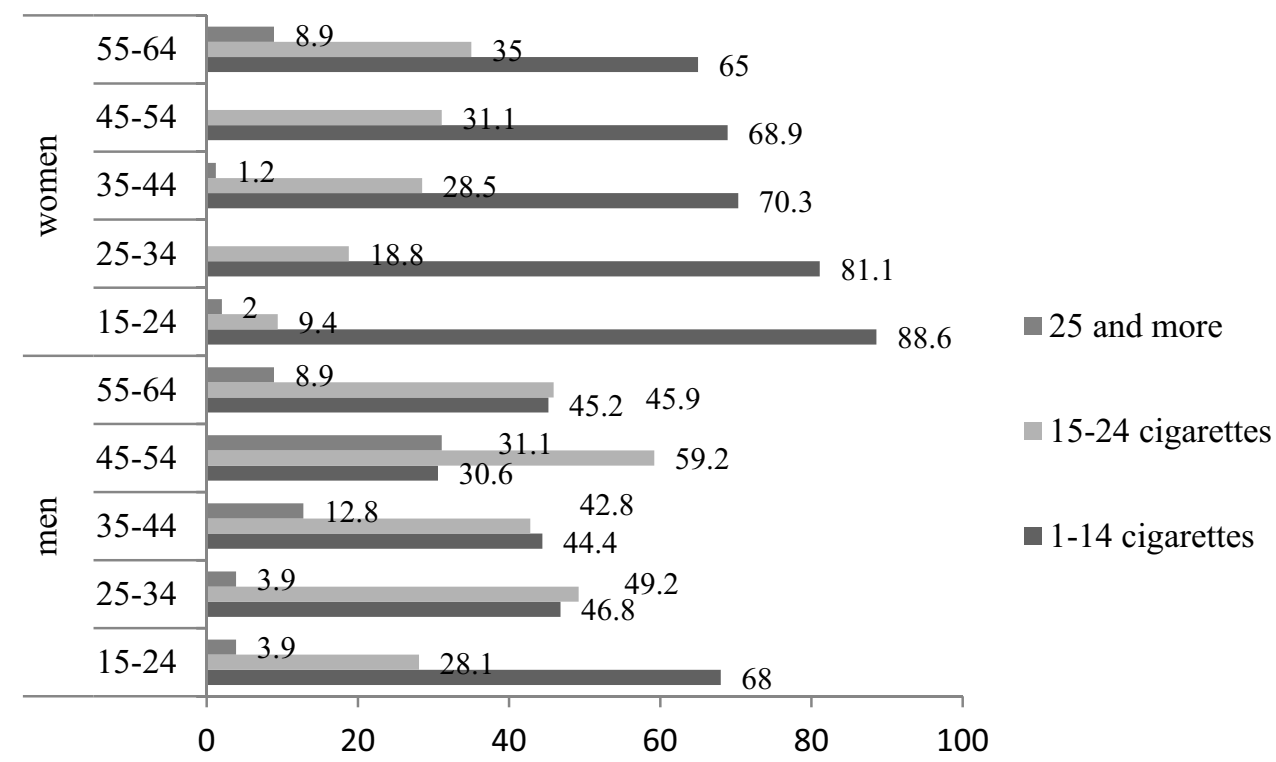

Figure 2. Proportion of cigarette smokers who smoke manufactured cigarettes daily.

diseases (SAD) in 2000 in Latvia was $5.9 \%$ of GDP or 501 million EUR. In 2000 Latvia's government spent $8.1 \%$ from the healthcare budget to treat SADs our 24 million EUR. The total spending for SAD in Latvia in year 2000 was 24 million EUR - 12\% for lung cancer, 5\% for all cancers and 56\% for CVD treatment [14]. Similar data was found in a study carried out in Germany in 2003 where $13.4 \%$ of all deaths were attributable to cigarette smoking. The number of YPLL totaled almost 1.6 million, of which 294000 could be assigned to the age group - 65 years (current statutory age of retirement for men in Germany) [15]. Study carried out in Georgia showed that by the calculations according to mortality data of year 2008 number of active smoking attributable deaths were 4331. Smoking was related with $10.1 \%$ of all deaths [16].

\section{Conclusions}

Latvia holds a leading position among European Union countries in smoking prevalence among working-age population. Until now, the country is mainly calculating the direct costs of smoking to the national economy caused by smoking: the health care costs, but more importantly it is to take into account the indirect costs caused by smoking: mortality costs. In Latvia, like in many other new EU Member States, the lack of data is the main cause which prevents comprehensive and objective analysis of the burden smoking causes to society. Smoking costs billions for Latvian economy, but due to the lack of data, the study does not take into account the expenditure individuals pay individually (out of pocket) and other indirect expenses, for example - disability, loss of employment, etc. As the major health consequences of smoking usually manifest themselves only after several years of smoking, both health-related and overall quality of life measurements could be used as an intervention tool for motivating people to quit. The study gives an insight in the economic burden Latvian government faces each year from tobacco smoking and it could be used as an introduction to further more detailed studies conducted by the government authorities. The study shows that we must reconsider the risk factors of smoking and keep in mind the threat for the 
national health and security system and provide prevention policy and action programs to lower the possible damage for the whole society, as they will pay for the smoking created burden.

\section{References}

[1] E. Jhonson, F. Dominici, H. Griswald, S.L. Zeger, Disease cases and their medical costs attributable to smoking: an analysis of the national medicalexpenditure survey. JEcon., 122, pp. 135-151 (2003). Available at http://www.biostat.jhsph. edu/ $\sim$ fdominic/papers/jec.pdf

[2] R. Doll, A.B. Hill, Lung cancer and other causes of death in relation to smoking. BMJ, 10, pp. 1072-1081 (1956). Available at http://www.ncbi.nlm.nih.gov/ pmc/articles/PMC2035864/

[3] U.S. Department of Health and Human Services, The Health Consequences of Smoking: 50 Years of Progress. SG, Atlanta, GA: U.S. Department of Health and Human Services, Centers for Disease Control and Prevention, pp. 7-8 (2014) World Health Organization, Economics of tobacco toolkit, Assessment of the Economic Costs of Smoking, pp. 8-19 (2011). Available at http://whqlibdoc.who.int/ publications/2011/9789241501576_eng.pdf

[4] Action on smoking and health, The economics of tobacco. 11 (2014). Available at http://www.ash.org.uk/files/documents/ASH_121.pdf

[5] J. Mackay, M. Eriksen, The Tobacco Atlas, WHO, pp. 40 (2002). Available at http://www . who.int/tobacco/media/en/title.pdf

[6] Action on smoking and health, The costs of smoking to the social care system in England, 9, pp. 5-6 (2014). Available at http://www.ash.org.uk/ localtoolkit/docs/SocCareCostsSum.pdf

[7] European Commission, Attitudes of Europeans towards tobacco, Eurobar, 385 (2012). Available at http://ec.europa.eu/health/tobacco/docs/eurobaro_ attitudes_towards_tobacco_2012_en.pdf

[8] Latvijas Republikas Veselības ministrija, Veselības nozares budžeta projekts 2014.gadam [The project for Health care systems budget, 2014] (2014). Available at http://www.vm.gov.1v/images/userfiles/2014_budzets_07_11_2013_ar_ otro_lasijumu.pdf (In Latvian).

[9] J. Gibson, R. Loddenkemper, S. Yves, B. Lundbäck, M. Fletcher, Lung health in Europe: Facts and figures European Respiratory Society, The European Lung White book, pp. 14-22 (2013). Available at http://www.erswhitebook.org/files/ public/About/Slideset $\% 20$ for $\% 20$ White $\% 20$ Book.pdf

[10] Center of disease control and prevention. Latvijas statistikas gadagrāmata 2012. [Statistical yearbook of health care in Latvia 2012 (2013). Available at file:///C:/Users/Raimonds/Downloads/2_Mirstiba_2012\%20(1).pdf (In Latvian).

[11] P. Boyle, Cancer, cigarette smoking and premature death in Europe: a review including the Recommendations of European Cancer Experts Consensus Meeting, Helsinki, October 1996, J of Lung Canc., May Issue, 17(1) pp. 1-60 (1997).

[12] I. Pudule, D. Grīnberga, B. Velika, I. Gavare, A. Villeruša, Latvijas iedzīvotāju veselību ietekmējošo paradumu pētījums, 2012 - 2 dalsa [Health behavior among Latvian adult population, 2012 - part 2], Slimību profilakses un kontroles centrs, pp. 74-77 (2013). Available at file:///C:/Users/Raimonds/Downloads/LV_ iedz_veselibu_ietekmejoso_paradumu_petijums_2012_II_dala\%20(1).pdf (In Latvian). 
[13] A. Jarvis, A. Vincze, B. Falconer, A. Garde, F. Gerber, R. Daynard, A study on liability and the health costs of smoking, European Commission DG Sanco (2009). Available at http://ec.europa.eu/health/tobacco/docs/tobacco_liability_en.pdf

[14] K. Gvinianidze, D. Tsereteli Tobacco smoking attributable mortality and years of potential life lost in Georgia, Georg. Med. New. 5 (206), 52-7 (2012).

[15] S. Neubauer, R. Welte, A. Beiche, H.H. Koenig, K. Buesch, R. Leidl, Mortality, morbidity and costs attributable to smoking in Germany: update and a 10-year comparison, Tobacco Control, 15, 464-471. DOI 10.1136/tc2006.016030 (2006). 